\title{
God nearby and God far away - Stephen Charnock on divine attributes
}

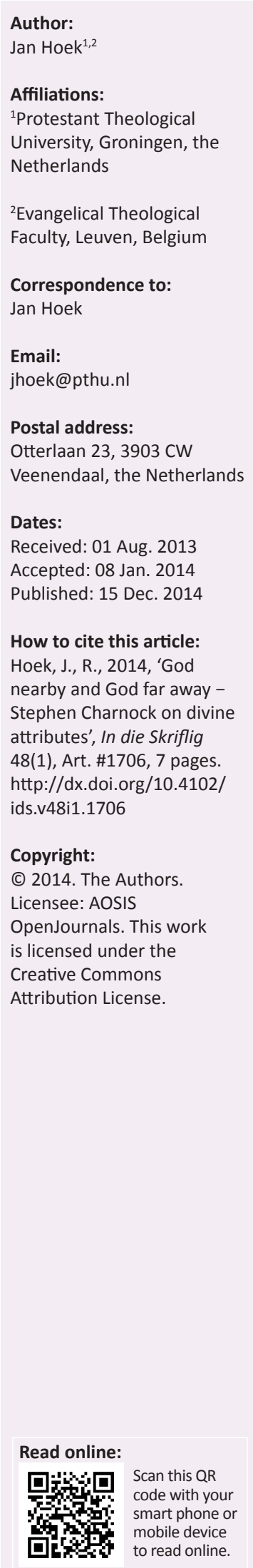

This article evaluated the way the Puritan theologian and pastor Stephen Charnock describes the attributes of God in his book titled Discourses upon the existence and attributes of God. On the one hand, the book displays a clear testimony to God's highness, 'God far away', which helps us overcome earthly conceptions of God's majesty. On the other hand, the book pays particular attention to the significance of experiential knowledge of God's attributes such as his omnipotence, holiness and goodness regarding the life of faith. This way, Charnock endeavours to preach 'God nearby'. The main question of research in this article is whether or not Charnock succeeded in establishing a connection between the attributes qualifying God as 'God far away' and those that depict him as 'God nearby'. Did he bridge the gap between these two approaches?

God nabij en God ver weg - Stephen Charnock (1628-1680) over de eigenschappern van God. Dit artikel evalueert de wijze waarop de Puriteinse theoloog en pastor Stephen Charnock in zijn boek Discourses upon the Existence and Attributes of God de eigenschappen van God bespreekt. Enerzijds is het boek een helder getuigenis van de grootheid van God, 'de God van verre', waardoor we geholpen worden om aardse voorstellingen van Gods majesteit te overwinnen. Tegelijkertijd geeft dit boek bijzondere aandacht aan de betekenis van de bevindelijke kennis van Gods eigenschappen, zoals zijn almacht, heiligheid, goedheid enzovoorts, in het leven van het geloof. Op deze wijze zet Charnock zich in om 'de God van nabij' te verkondigen. De belangrijkste vraag die dit artikel wil beantwoorden is in hoeverre Charnock erin slaagt een brug te slaan tussen deze beide benaderingen.

\section{God nearby and God far away - Stephen Charnock (1628-1680) on divine attributes}

A vital issue in current debates in the field of systematic theology is simply referred to as 'Godtalk' (cf. Braaten 1989). How do we talk about God in a befitting manner? It is crucial to do justice to God's transcendence as well as his immanence or condescension; to God's highness as well as his nearness in Christ. In several present-day approaches of theology proper, one gets the impression that the warning word of God, delivered by the mouth of the prophet Jeremiah, has to be taken to heart again: 'Am I only a God nearby, declares the LORD, and not a God far away?' (Jr 23:23, NIV). This reminds us of Lord's Day 46 of the Heidelberg Catechism that raises a question regarding the onset of the Lord's Prayer:

Why is it here added 'Which art in heaven?' Answer: 'Lest we should not form any earthly conceptions of God's heavenly majesty, and that we may expect from his almighty power all things necessary for soul and body'.

As a matter of fact, we see instances of earthly conceptions of God in several contemporary theological and philosophical approaches, for instance where God is depicted as weak and needy instead of sovereign and powerful (e.g. 'the fellow-sufferer who understands', A.N. Whitehead). When suffering is placed at the heart of God, as Jürgen Moltmann does in his Theologia Crucis, there is the real danger that we end up with a God who is as helpless as we are in the face of suffering and evil, and whose freedom and transcendence is seriously compromised (cf. Marmion \& Van Nieuwenhove 2011:174).

This article aims to show how a renewed acquaintance with the work of a representative classical reformed theologian, to wit the Puritan pastor Stephen Charnock (1628-1680), will help us overcome our tendency to entertain earthly conceptions regarding God's majesty. We may view Charnock's book Discourses upon the existence and attributes of God (posthumously published in 1682 and a primary source for this article) as a long doxology (cf. Beeke \& Jones 2012; Trueman 2008). Stephen Charnock died before he could finish his treatises on God's attributes for his nonconformist 
congregation in Crosby Hall, England. The book was widely appreciated. ${ }^{1}$ His considerations are largely in concordance with established views of Reformed Orthodoxy on the highly significant topic of the doctrine of God (Muller 2003; Beck 2007; Te Velde 2010). At the same time, Charnock's contribution is remarkable as he excels in succinct and clear formulations, showing an impressive way how the glorious attributes of God bear a comfortable respect to believers. His discourses are really addressed to the hearts of his readers (Symington 1979) and make clear how the divine attributes are great motives to provoke men to the exercise of faith, love, hope, fear and humility (Veel \& Adams 1979).

Charnock makes it clear from the outset that he intends to proclaim the unique highness and holiness of God. In his view, God is first and foremost 'the God far away'. It would be of great value if this approach were to be reintroduced in a refreshing manner to contemporary theological debates. However, in order to sidestep one-sidedness, this article investigates to what extent Charnock shows himself capable of relating God, as the 'perfect Being', to human beings in a salvific way. Is the God he speaks of also the 'God nearby', known by his children as a heavenly, caring Father?

It is not the intention to summarise Charnock's theological description of several attributes of God at length, but just to call attention to his impressive testimony of the greatness of God. Secondly, this article will shed some light on the way he reaps the pastoral fruits of his discourses to enrich the believers' experiential knowledge of God. As was usual in his spiritual environment, Charnock concludes his discourses (a type of sermon) with several practical applications or 'uses' (instruction, exhortation, consolation, etc.) in order to relate doctrine to life. Especially in the 'uses of consolation', he sincerely strives to maintain the paradox of the transcendent and immanent - the far and near God. Does he succeed in this endeavour, affording us a clear view of the merciful nearness of the heavenly Father?

\section{Attributes of 'the God far away' Spirit}

The first thing that Charnock underscores in his treatises on God is that he is a Spirit. ${ }^{2}$ There is no corporeality or materiality in God and so God's Being is non-composite, Charnock (1682, vol. 1:187). God is a Spirit qualified by reason and will, which are totally holy, wise, good and just. 'Spirit' is in our human nature and, according to our notions, the highest conceivable thing. We therefore apply this notion to God having nothing better. At the same time, we have to perpetually consider that our words and notions can never reach the level of the highest God, Charnock (1682, vol. 1):

Whatsoever God is, he is infinitely so: he is infinite Wisdom, infinite Goodness, infinite Knowledge, infinite Power, infinite Spirit; infinitely distant from the weakness of creatures, infinitely mounted above the excellencies of creatures. (p. 200)

1.Beeke and Jones (2012:59): "... perhaps the most extensive and incisive Puritan treatise on the doctrine of God'.

2.Cf. Westminster Confession of Faith 2.1.
As the most perfect Being, 'God, as immutable, is opposed to all creatures as perishing and changeable [...] Mutability is absolutely inconsistent with simplicity, whether the change comes from an internal or external principle', Charnock (1682, vol. 1:187, 317).

\section{Eternity}

Writing about God's eternity (aeternitas), Charnock selects Exodus 3:14 as the pivotal text. God is the great 'I AM'. $\mathrm{He}$ is the only Being in the true sense of the word - the root of all beings, eternally and immutably the same. 'Eternity is only proper to God, and not communicable' (Charnock [1682, vol. 1:291]; cf. 1 Tm 6:16) - it is barely fathomable and even more difficult to express. It must be regarded as a permanent and immutable existential form and a perfect possession of life without any variation, beginning or end. Any evolution or growth of God's essence is impossible by definition, Charnock (1682, vol. 1:284).

\section{Immutability}

God does not change and cannot change. The immutabilitas [immutability] of God's will is accompanied by perfect freedom. When God acts in time, nothing changes in his essence. When he, for instance begins to create, he does so because he is essentially the Creator and decides freely to actualise this property at a moment determined by him. If he had not chosen to create, he would essentially remain the Creator. $^{3}$

God always acts according to the holiness of his essence and can no more alter in his attitude regarding good and evil than he could alter his essence. God is necessarily immutable and fully free at the same time. Nothing and nobody compelled him to decide or to create. It was nevertheless, his establishment to do so. In the same way, it was certain that Adam would fall, whilst Adam did so totally voluntarily. ${ }^{4}$ This creates an indissoluble paradox to our understanding. It is impossible for us as creatures to fully comprehend the ways of the glorious God.

\section{Omnipresence}

Charnock connects the omnipresence of God (omnipresentia Dei) with Jeremiah 23:24 - God is omnipresent in heaven and on earth. He knows neither bounds nor limitations. 'God is totally everywhere by his own simple substance', Charnock (1682, vol. 1:375). When it is stated that God lives in heaven, it is intended that heaven is directed upon as the court of God's majestic presence, but not the prison of his essence, Charnock (1682, vol. 1:385). Like Augustine said, we move in God as a sponge moves in the sea. The sponge does not contain the sea, but the sea contains the sponge. There is no room for pantheism or panentheism. The Creator contains the world the world does not contain the Creator.

3.Charnock (1682, vol. 1:339): 'So the name Creator and Lord belongs to God from eternity, because he could create and rule, though he did not create and rule [...] so that suppose any new relation be added, yet there is nothing happened to the nature of God which may infer any change.'

4.Charnock (1682, vol. 1:450): 'Adam was not determined by any inward necessity to fall, nor any man by any inward necessity to commit this or that particular sin; but God foresaw that he would fall, and fall freely.' 


\section{Omniscience}

The omniscience of God (omniscientia Dei) is tightly linked to his perfect wisdom. Wisdom is the flower of knowledge and knowledge is the root of wisdom, Charnock (1682, vol. 1:410). God is the only One who fully knows himself in a perfect and encompassing way. God is the only perfect Theologian, Charnock (1682, vol. 1:416). Furthermore, he knows everything that exists. God cannot gain new knowledge, since his knowledge is perfect by definition. God's knowledge of the future is not conjectural nor dependent on circumstances independent of his will, as the idea of the scientia media or conjecturalis implies (which is an unworthy notion to ascribe to God, according to Charnock).

\section{Wisdom}

Perfect wisdom (sapientia) goes together with omniscience. Knowledge is more speculative - wisdom is more practical as the source of application. God's wisdom is connected to power. 'Wisdom is naked without power to act, and power is useless without wisdom to direct', Charnock (1682, vol. 1:501). Knowledge is the infrastructure of wisdom and wisdom is the superstructure of knowledge. Wisdom is the most brilliant of all God's virtues. 'Wisdom is the royalty of God; the proper dialect of all his ways and works', Charnock (1682, vol. 1:506). Without wisdom, all other attributes are like a body without eyes - a soul without understanding. The patience of God would be cowardice - his power oppression, his justice a tyranny - without wisdom as the source and holiness as its rule. Wisdom is the salt giving relish to all the other attributes. Wisdom is the jewel in the ring of all the excellences of the divine nature, whilst holiness is the splendour of that jewel, Charnock (1682, vol. 1:515).

\section{Powerful}

We cannot have a conception of God if we do not conceive him as most powerful (omnipotens). God can do all that he can will; he cannot do what he cannot will. As an infinite essence, he must have an infinite power of activity. God's power is his strength to act.

We need to know the difference between the might or power of God and his dominion. God has not only the might, but also the right to do what he wants to do. His strength is the executive power belonging to his dominion. All the other attributes of God refer to this perfection of dominion.

\section{Holiness}

In Scripture God is often described as 'the Holy One of Jacob/Israel' - he is more frequently entitled as holy than almighty. 'This is his greatest title of honour; in this does the majesty and venerableness of his name appear', Charnock (1682, vol. 2:110). If any, this attribute has an excellence above his other perfections. It is the glory of every perfection in the Godhead, Charnock (1682, vol. 2):

As his power is the strength of them, his holiness is the beauty of them. As all would be weak, without almightiness to back them, so all would be uncomely without holiness to adorn them
[...] Without it, his patience would be an indulgence to sin, his mercy a fondness, his wrath a madness, his power a tyranny, his wisdom an unworthy subtlety. (pp. 113-114)

The holiness of God is a perfect and unpolluted freedom from all evil. He has a delight and complacency in everything agreeable to his will. He also has an abhorrence of everything contrary thereunto, Charnock (1682, vol. 2:114, 115).

\section{Attributes of the 'God nearby'}

Most attributes described by Charnock are those of the 'God far away', but he also attends to some attributes that exemplify the 'God nearby' such as goodness, mercy and patience.

\section{Goodness}

Pure and perfect goodness is the royal prerogative of God alone - it is a choice perfection of the divine nature. This is the true and genuine character of God. Whatsoever is perfect goodness, is God; whatsoever is truly goodness in any creature, is a resemblance of God, Charnock (1682, vol. 2:214). In the same manner as a good tree bears good fruits, God's goodness shines forth in all his works.

The goodness of God is not the same as the mercy of God. The goodness of God goes together with his mercy, which extends itself to men in misery and distress. God is good in essence ([per essentiam; simplicitas] Dei II:221). Goodness is not an endowed quality in him - it is his nature. He is not God first, followed by goodness. His essence is formally and equally God and good. God is the prime and chief goodness. All good must be referred to him, as he is the final cause of good. This goodness is communicative, Charnock (1682, vol. 2:223). As the highest goodness, he is a communicative goodness. God is necessarily good, Charnock (1682, vol. 2:224). His goodness is as inseparable from him as his holiness. He can no more act contrary to his goodness in any of his actions than he can 'un-God' himself. He is also freely good, Charnock (1682, vol. 2:226). He is not so necessarily communicative of his goodness as the sun of its light, or a tree of its cooling shade. He is an understanding agent, and he has a sovereign right to choose his own subjects. His own happiness cannot more be diminished than it can be increased. The display of this goodness was the motive and end of all his works of creation and providence, Charnock (1682, vol. 2:228).

God manifests his goodness in creation, redemption and providence, Charnock (1682, vol. 2:244). The creation proceeds from goodness. Being is much more excellent than nothingness. God's goodness appears in the laws he has given to man in the covenant he has made with him, Charnock (1682, vol. 2:252). It was God's sheer goodness to reward the obedience of man with eternal happiness, Charnock (1682, vol. 2:257).

Goodness was also the source of redemption, Charnock (1682, vol. 2:258). He was under no obligation to pity our misery and to repair our ruins. It was a distinct goodness of the whole Trinity, Charnock (1682, vol. 2:260). The height of this goodness in redemption exceeds that in 
creation, with regard to the difficulty in effecting it and with regard to its cost, Charnock (1682, vol. 2:261). In God's giving of Christ to be our Redeemer, he gave the highest gift that divine goodness could bestow, Charnock (1682, vol. 2:266). Never did God go further in any of his excellent perfections than this. Although he could create millions of worlds for us, he cannot give a greater Son to us. This goodness also appears in the higher advancement of our nature after it had so highly offended God. By creation, we had an affinity with animals in our bodies, with angels in our spirits and with God in his image, but not with God in our nature until the incarnation of the Redeemer, Charnock (1682, vol. 2:273). Our earthly nature is joined to a heavenly Person. There are fuller streams of grace through Christ than flowed to Adam, or that could flow from Adam, Charnock (1682, vol. 2:291).

\section{Patience and mercy}

God is patient, since he is èrèk appajim [of broad nostrils]. His power moderates his anger. God's slowness to anger is a branch or slip from his mercy. Mercy respects the creature as miserable; patience respects the creature as criminal. Mercy pities it in its misery; patience bears with the sin, which engendered that misery. 'He waits that he may be gracious' (Is 30:18). The exercise of patience being a branch of mercy is founded in the death of Christ. Without considering this, we can give no account as to why divine patience should extend itself to us, and not to the fallen angels, Charnock (1682, vol. 2:482). God's justice and righteousness are not prejudiced by his patience. If he should presently execute his justice, this perfection of patience, which is a part of his goodness, would never have an opportunity of being discovered. One perfection must not cloud another. Mercy has a heaven and justice a hell to display itself to eternity, but God's long-suffering only has a short-lived earth for the compass of its operation, Charnock (1682, vol. 2:486).

\section{Bridging the gap}

Having considered two series of divine attributes, we can try to answer the question to what extent Charnock safeguards the consistency of his testimony of God. In this way he bridges the possible gap between God's austerity and his compassion by indicating the salutary significance of God's attributes for the believers. Illustrative are his remarks regarding God's eternity, Charnock (1682, vol. 1):

Since God is eternal, he hath as much power as will to be as good as his word. His promises are established upon his eternity; and his perfection is a main ground of trust. (p. 300)

The eternal God affords eternal joy, Charnock (1682, vol. 1):

The fullness of joy will be always present; without past to be thought of with regret for being gone; without future to be expected with tormenting desires. When we enjoy God, we enjoy him in his eternity without any flux [...] Time is fluid, but eternity is stable; and after many ages, the joys will be as savory and satisfying as if they had been but that moment first tasted by our hungry appetites. (p. 298)

The church is encouraged by God's immutability in the midst of her oppressions, Charnock (1682, vol. 1):
Yet the church should continue in its stability, because it stands not upon the changeableness of creatures, but it is built upon the immutable rock of the truth of God, which is as little subject to change as his essence. (pp. 310-311)

The immutability of a good God is the basis and strength of all his promises. The covenant stands unchangeable. He will not revoke the covenant, and will never blot the names of his elect out of the book of life. 'What comfort could it be to pray to a God, that like the chameleon changed colors every day, every moment?' Charnock (1682, vol. 1:348).

Also, God's omnipresence is a great comfort to believers. He is everywhere to his people - not only by a necessary perfection of his nature, but by an immense diffusion of his goodness. He is with his people as light in darkness, as a fountain in a garden, as manna in the ark. The omnipresence of God is a comfort in all violent temptations and sharp afflictions. It is a comfort in all duties of worship. God is present to observe and to accept our petitions, and answer our suits. $\mathrm{He}$ is as genuinely present with us as if he were visible to us, Charnock (1682, vol. 1):

He is in the same room with us, as near to us as our souls to our bodies, not a word but he hears, not a motion but he sees, not a breath but he perceives; he is through all, he is in all. (p. 401)

The comfort of God's omniscience is that he knows all the clandestine contrivances of men against the church. On the other hand, our sincerity cannot be unknown to his infinite understanding, Charnock (1682, vol. 1):

As he understands better than we what we have committed, so he understands better than we what our Saviour hath merited; and his eye directs his hand in the blotting of our guilt, and applying the remedy. (p. 491)

What joy can he be missing who finds himself folded in the arms of omnipotence? A comfort in all afflictions and distresses, and in all strong and stirring corruptions and mighty temptations - knowing that all promises shall be effectuated. From this infiniteness of power in God, we have ground of assurance for perseverance. 'Our keeping is not in our weak hands, but in the hands of Him who is mighty to save. That power of God keeps us which intends our salvation', Charnock (1682, vol. 2:100):

It is a great comfort that the lowest distresses of the church are a fit scene for the discovery of this attribute, and that the glory of God's omnipotence, and the church's security, are so straitly linked together. Charnock (1682, vol. 2:101-102)

God's sovereignty and dominion is a strong encouragement for prayer. Comfort in affliction, in adversity directed at the church and in times of public commotion may be found in it. Who can repeal the act of the chief Governor?

The holiness of God appears in our restoration. It appears, for example in the actual regeneration of the redeemed souls and in completing this to full perfection. His holiness is radiated in our purity, Charnock (1682, vol. 2): 
As he sent Jesus Christ to satisfy his justice for the expiation of the guilt of sin, so he sends the Holy Ghost for the cleansing of the filth of sin, and overmastering the power of it: Himself is the fountain, the Son is the pattern, and the Holy Ghost the immediate imprinter of this stamp of holiness upon the creature. (p. 139)

The goodness of God renders him amiable, more so than any other attribute, Charnock (1682, vol. 2:330). This renders God a fitting object of trust and confidence, Charnock (1682, vol. 2:335). A confidence in him gives him the glory of his goodness. His goodness makes him more ready to forgive than our necessities make us desirous to enjoy. If he is a fountain and sea of goodness, he cannot be weary of doing good, no more than a fountain or sea can be weary of flowing. It is a part of his goodness not to be weary of showing it. What can we fear from the conduct of infinite Goodness? It is a basis for assurance and happiness, and also for comfort in the midst of public dangers, Charnock (1682, vol. 2:344).

This goodness is also manifested in his dominion in the care he extends to all creatures; in preserving all things; in taking care of wicked individuals; in the preservation of human society; in the encouragement of any form of moral goodness in the world; in providing a Scripture as a rule to guide us and continuing it in the world; in conversions of men; in answering prayers; in bearing with the infirmities of his people; and accepting imperfect obedience in afflictions, persecutions and temptations, Charnock (1682, vol. 2:449f.).

God's patience is a basis for trusting his promises and it is a comfort in infirmities, Charnock (1682, vol. 2:516). We are called to imitate God's patience in our dealings with others. As his slowness to anger argues the greatness of his power over himself, such unwillingness to vengeance is a sign of a power over ourselves, which is nobler than ruling over others, Charnock (1682, vol. 2:524).

\section{The remaining cleft}

Charnock is very eloquent and abundant in his consolations. Nevertheless, it must be said the impression that he is not always successful in his endeavours in bridging the gap, and so a cleft remains, will now be illustrated through a number of examples.

\section{Ambiguous accommodation}

According to Charnock, God himself cannot be subject to change. Repentance is not 'properly' in God. To attribute proper repentance to God would be to deny his foreknowledge: 'But God accommodates himself in the Scripture to our weak capacity. God hath no more of a proper repentance, than he hath of a real body', Charnock ([1682, vol. 1:341], cf. Huijgen 2011; Theron 2013). 'He is a pure Spirit, and is not capable of those passions which are signs of weakness and impotence or subject to those regrets we are subject to', Charnock (1682, vol. 1:340-341). ${ }^{5}$

5.Cf. Webster's Third New International Dictionary s.v. 'passion', definition 4a. There is nothing in God that subjects him to, or renders him liable to be acted on, by what is external or foreign to his true nature.
Charnock therefore argues that we should always call attention to the notion that God speaks about these things in an accommodated way - in the same way that nurses speak to sucklings. As a matter of fact, God has no more emotions like we experience than he has hands and feet of flesh and blood like we have. God's inability to experience emotions as we do, is no defect in him - it exemplifies his perfection. Charnock makes a remarkable comparison, using biblical imagery about heaven, sea and earth, to which emotions are also ascribed (e.g. in Ps 98). It is clear that mountains cannot jump for joy and that rivers cannot applaud. That would be contrary to their nature. Likewise, emotions do not fit the nature of God, Charnock (1682, vol. 1):

Or else we may understand those expressions of joy, and grief, and repentance, to signify thus much, that the things declared to be the objects of joy, and grief, and repentance, are of that nature, that if God were capable of our passions [author's italics], he would discover himself in such cases as we do; as when the prophets mention the joys and applaudings of heaven, earth, and the sea, they only signify that the things they speak of are so good, that if the heavens and the sea had natures capable of joy, they would express it upon the occasion in such a manner as we do; so would God have joy at the obedience of men, and grief at the unworthy carriage of men, and repent of his kindness when men abuse it, and repent of his punishment when men reform under his rod, were the majesty of his nature capable of such affections. (p. 342, [author's italics])

This means that every mention of God's hands, feet, eyes and ears must be considered a condescension and accommodation to our weakness. Charnock warns his readers they should never make the mistake to take this imagery literally. God must be served in a spiritual way (Jn 4:24). The smallest worship with the heart and the spirit, flowing from a principle of grace, is more acceptable than the most pompous veneration.

The stress on accommodation is ambiguous and not without real danger. The reliability of God's revelation is at stake here. It is clear that God never has to repent like we do, but that does not hinder him from repenting in his own way. The God of Scripture is constantly reacting on human action and condition - he is not in the least metaphysically isolated or detached from, unconcerned with, insensitive to or indifferent to the condition of fallen men.

\section{Contentious impassibility}

According to Charnock God is impassible, being in concordance with the orthodox theological tradition. What he means by this is that God is unlike men who do not have full control over their passions. This is a relevant observance. God cannot be touched by the violence of human beings against his will and his essential glory cannot be diminished by the injuries of men. God can only suffer if he freely chooses to suffer and if that mode of suffering is in accordance with his very essence as the living God. God's experiences are not involuntary surprises forced upon him from outside, apart from his own decision. God's passions are to be interpreted in suitableness to divine perfection and blessedness. 
However, any denial of the reality of God's emotions makes it - this article contends - impossible to ascribe weight to the reliability of God's revelation. All 'God-talk' has a metaphorical character. This, however, does not water down the reliability of the biblical language concerning God. ${ }^{6}$ God's essential properties are the same from eternity until eternity, but experientially they become astonishingly new in the daily and practical interaction with his people. God is always timely in his immutability. Scripture provides a clear testimony of a God having passions. ${ }^{7}$ God is acquainted with joy, anger, jealousy, repentance and even hatred. His nostrils become red from his anger and his bowels rustle in compassion for his people (cf. Is 63:15). The New Testament shows how this personal and passionate God is the One who - in compassion and love - has taken effective steps in Jesus Christ to reverse the misery of men (Reymond 1998):

Everywhere He is portrayed as One who can and does enter into deep, authentic interpersonal relations of love with his creatures, and as a God who truly cares for his creatures and their happiness. (p. 178)

\section{Inconceivable providence}

A piercing question is how God's wisdom relates to the evil in the world. According to Charnock, the permission of sin is an act of God's sovereignty, the punishment of sin is an act of his justice and the ordination of sin to good is an act of his wisdom. Sin in itself is a disorder, and therefore God does not permit sin for itself, but he wills it for some rightful ends, which belongs to the manifestation of his glory. He makes it contribute to the beauty of the order he intends. God permitted Adam's fall, and wisely ordered it, for a fuller discovery of his own nature and a higher elevation of man's good. The unbounded goodness of God could not have appeared without it. His goodness in rewarding innocent obedience would have been manifested, but not his mercy in pardoning rebellious crimes. Nothing serves God so much as an occasion for glorifying himself as the entrance of sin into the world. God even ordered - by infinite wisdom - the fall of the devil. The great reason why God permitted sin to enter into the world was to honour himself in the Redeemer. The brightness of Christ's grace is a stark contrast to the darkness of our sin. 'To will sin as sin, would be an unanswerable blemish on God, but to will to suffer it in order to good, is the glory of his wisdom', Charnock (1682, vol. 2:149). The works of creation are the footsteps of his wisdom - the work of redemption is the face of it. By his wisdom, God deals with our sins in a way of consuming justice, and with our persons in a way of relieving mercy, Charnock (1682, vol. 1:567).

These considerations evoke many critical questions. Can we speak about sin as a link in the chain of God's decrees? Should we not leave these kinds of 'answers' and 'explanations' out when we are confronted with the mysterium iniquitatis [the riddle of sin and injustice]? Is the way Charnock

6. Religious propositions regarding God have the intention to refer to an externa reality, which is not to identify with the believers themselves. They contend cognitive claims and pretend to be ontologically right.

7.See Köhler (1953:4): 'In grosser Ausführlichkeit liegt unbekümmert und selbst drastisch die menschenartige Anschauung von Gott auf allen Blättern des AT hingebreitet.' speaks about God's providence not too far-reaching and, in a sense, naive? Such an approach could easily lead to the justification of structural iniquity. We notice this when Charnock, affirming that all God's laws are suited to the true satisfaction of man and the good of human society, contends that poverty has a certain positive aspect. Some people are rich and some poor. The rich have as much need of the poor as the poor have of the rich: if the poor depend upon the rich for their livelihood, the rich depend upon the poor for their conveniences, Charnock (1682, vol. 1):

If all were rich, there would be no objects for the exercise of a noble part of charity; if all were poor, there we no matter for the exercise of it. Thus the Divine wisdom planted various inclinations and diversified the conditions of men for the public advantages of the world. (p. 532)

These words can be misused to foster a conservatism that impedes any societal criticism and renewal.

\section{Impenetrable predestination}

As a reformed theologian, Charnock defends the eternal predestination of the elect and the reprobate. God's dominion is evident in the selection of some persons for eternity. This is his royal prerogative. The absolute sovereignty of God is the only cause of election. Justice and injustice do not come into consideration in this case. If it had pleased him, he might have chosen all - if not, he might have chosen none. The dominion of God is manifested in him being a Redeemer, as well as Lawgiver, Proprietor and Governor, in the way he has appointed Christ to the work of redemption, et cetera.

The providence of God or the absolute predestination is described here in such an abstract manner that too little room is left for the difficult questions and puzzling paradoxes that will always accompany a theologia viatorum [a theology of people who are living by faith and not by observing] (cf. Schwarzwäller 1970).

\section{Evaluative remarks}

Charnock unquestionably demonstrates a remarkable view on the emotions of believers in their knowledge of Gods' attributes: 'If we understand the amiableness of God, our affections will be ravished; if we understand the immensity of his goodness, our spirits will be enlarged', Charnock (1682, vol. 1:227). Correct conceptions in our minds of God's majesty lead to true affections considering him as the most amiable object, the best of beings, worthy of infinite honour, Charnock (1682, vol. 1:272). We may draw near to God with cheerfulness, and at the same time with deepest reverence, purity and humility, knowing that he is a Spirit infinitely provoked by us. We must therefore offer our worship to the name of a pacifying Mediator and Intercessor, Charnock (1682, vol. 1:242).

These are beautiful passages indeed and they abound in Charnock's work. Nevertheless, theological criticism is in 
place and even necessary. Concerns may concentrate on the disproportionate stress that Charnock places on the attributes of God's transcendence, which results in the underestimation of the attributes of God's immanence or condescension. Charnock chooses to explain everything by appealing to God's sovereignty. Why not respect the mysterium iniquitatis instead of justifying evil and sin as a means to glorify God? It is sometimes difficult to recognise the Father of Jesus Christ in such considerations. The orthodox reformed discourses on God, as exemplified by Charnock, therefore need to be completed and corrected by an approach from the opposite direction - visually starting with the attributes of God's immanence and viewing the attributes of God's transcendence in the light of the former (cf. Van den Brink \& Van der Kooi 2012:126f.). Nevertheless, the theological contribution of Charnock must be welcomed as relevant and valuable to the ongoing debate concerning 'God-talk'. By his stress on God's transcendence, he helps us to give testimony to the God who is both a God far away and a God nearby our Father in heaven.

\section{Acknowledgements Competing interests}

The author declares that he has no financial or personal relationship(s) that may have inappropriately influenced him in writing this article.

\section{References}

Beck, A., 2007, Gisbertus Voetius (1589-1676): Seine Theologieverständnis und seine Gotteslehre, Vandenhoeck \& Ruprecht, Göttingen. http://dx.doi. org/10.13109/9783666551000

Beeke, J.R. \& Jones, M., 2012, 'Stephen Charnock on the attributes of God', in J.R. Beeke \& M. Jones (eds.), A Puritan Theology: Doctrine for life, pp. 59-84, Beeke \& M. Jones (eds.), A Puritan The
Reformation Heritage Books, Grand Rapids.

Braaten, C.E. (ed.), 1989, Our naming of God: Problems and prospects of God-talk today, Fortress Press, Minneapolis.

Charnock, S., 1682, Discourses upon the existence and attributes of God, vols. 1 \& 2, Baker Bookhouse, Grand Rapids.

Huijgen, A., 2011, Divine accommodation in John Calvin's theology: Analysis and assessment, Vandenhoeck \& Ruprecht, Göttingen.

Köhler, L., 1953, Theologie des Alten Testaments, J.C.B. Mohr (Paul Siebeck), Tübingen.

Marmion, D. \& Van Nieuwenhove, R., 2011, An introduction to the Trinity, Cambridge University Press, Cambridge.

Muller, R.A., 2003, Post-Reformation Reformed Dogmatics: The divine essence and attributes, vol. 3, Baker Academic, Grand Rapids.

Reymond, R.L., 1998, A new systematic theology of the Christian faith, Thomas Nelson Publishers, Nashville.

Schwarzwäller, K., 1970, Das Gotteslob der angefochtenen Gemeinde: Dogmatische Grundlegung der Prädestinationslehre, Neukirchener Verlag, Neukirchen.

Symington, W.M., 1979, 'Life and character of Charnock', Discourses 1, 6-18, 15.

Te Velde, D., 2010, Paths beyond tracing out: The connection of method and content in the doctrine of God: Examined in Reformed Orthodoxy, Karl Barth and the Utrecht School, Eburon, Delft.

Theron, P., 2013, 'Accommodation and incarnation: A favourite concept of Calvin in the theology of Oepke Noordmans', in $\mathrm{H}$. van den Belt (ed.), Restoration through redemption. John Calvin revisited, pp. 199-214, Brill, Leiden. http://dx.doi. org/10.1163/9789004244672_014

Trueman, C., 2008, 'Reason and rhetoric: Stephen Charnock on the existence of God', in M.W.F. Stone (ed.), Reason, faith and history: Philosophical essays for Paul Helm, pp. 29-46, Ashgate, Aldershot.

Van den Brink, G. \& Van der Kooi, C., 2012, Christelijke Dogmatiek - Een inleiding, Boekencentrum, Zoetermeer.

Veel, E. \& Adams, R., 1979, 'To the reader', Discourses I, 19-22, 22.

Westminster Confession of Faith 2.1. 